\title{
無血清培鉴下における正常口腔粘膜上皮細胞唾液腺 上皮細胞ならびにロ腔癌細胞の脂質代謝
}

\author{
新木恒猪・岡本哲治・高田和彰
}

\section{Lipid metabolisms of normal epithelial cells and cancer cells derived from oral region in serum-free culture}

\author{
Tsunei Shinki - Tetsuji Oкамото $\cdot$ Kazuaki Takada
}

\begin{abstract}
We have previously reported that sensitivity to various antitumor drugs on squamous carcinoma cells is different from that on adenocarcinoma cells. Furthermore, the difference is well correlated with the ability of the cells to incorporate drugs by passive transport. These results suggest the possibility that the accumulation of the drug was closely associated with lipid composition and/or conformation which is thought to be an important factor to determine hydrophobicity of the cell membrane.

Generally, serum-contained medium was used to study lipid metabolism in cultured cells. Since lipid metabolism is dependent upon the presence of external lipoproteins, we have studied lipid metabolism of normal epithelial and cancer cells in serum-free culture to evaluate intrinsic lipid metabolism in the cells.

$\left[2-{ }^{14} \mathrm{C}\right]$ acetate was incorporated almost exclusively into phospholipids in oral epithelial cells cultured in a low calcium medium. However when the concentration of calcium was changed from $0.03 \mathrm{mM}$ to $1.12 \mathrm{mM}$ to induce terminal differentiation of the cell, a definite amount of radioactive acetate was incorporated into free cholesterol and incorporation into phospholipids was decreased. The extent of the incorporation into free cholesterol was increased at least until $48 \mathrm{hrs}$ after inducing differentiation and the ratio of free cholesterol over phospholipids were constantly increased in this period, indicating that accumulation of free cholesterol is concomitant with the differentiation of the cell. Furthermore, it may be suggested that the ratio of free cholesterol over phospholipid could be an indicator for terminal differentiation of epithelial cells. Squamous cell carcinoma cells which showed a decreased capacity to differentiate exhibited increased incorporation into phospholipids and decreased incorporation into neutral lipids. On the other hand, adenocarcinoma cells showed marked differences in lipid metabolism compared to squamous carcinoma cells, i.e., increased incorporation into neutral lipids and decreased incorporation into phospholipids.

From the results obtained, it is clear that a close relationship exists between lipid metabolism and the ability of cells to differentiate. Furthermore, it may be suggested that hydrophobicity of the cell membrane in squamous carcinoma cells might be higher than that in adenocarcinoma cells.
\end{abstract}

Key words : cancer cells（癌細胞)， lipid metabolism，(脂質代謝)， serum-free culture（無血清 培養）

広島大学齿学部口腔外科学第 1 講座

(主任 : 高田和彰教授)

Department of Oral and Maxillofacial Surgery I,
Hiroshima University, School of Dentistry (Chief: Prof. Kazuaki Takada)

受付日：平成 3 年 9 月 24 日 


\section{緒}

われわれはすでに口腔由来扁平上皮癌細胞と唾液腺由 来腺癌細胞の種々の抗癌剂に対する感受性に大きな差が あること，さらにその差は膜の受動輸送による抗癌剤の 細胞内への取り込又能の差を反映していることをあきら かにしてきた ${ }^{1,2)}$. これら癌細胞における薬剂の取り込 みの差は, 細胞膜の脂質構造の違いに基づく細胞膜の疎 水性の差を反映している可能性が考えられる.

従来, 培養細胞に打ける脂質合成能の検索は, 血清を 含む培地を用いて行われている，血清中にはリポ蛋白を 中心とした脂質や未知の因子が存在して扔り ${ }^{3)}$, これら はまた血清のロットによっても変化する。このような培 養条件では細胞が本来持つ脂質合成能を正確に検索する ことは不可能である。

一方, D. Barnes 扰よび G.H. Sato $5^{4,5)}$ は血清の 主な役割は細胞の增殖にとって必要なホルモン, 細胞増 殖因子を細胞に供給することであるという仮説をもと に，基礎培地に既知の細胞増殖因子やホルモンを加えた 無血清培地を用いて，動物細胞の増殖のみならず機能を も維持することに成功し，無血清培養法を確立した。し たがって脂質を含まない無血清培地を用いることにより 細胞が本来もつ脂質合成能の検索が可能となると考えら れる. 今回，われわれは当科で開発した無血清培地 ${ }^{6)}$ 用いてロ腔粘膜由来並びに唾液腺由来正常上皮細胞扣よ びロ腔癌細胞の培養を行い，それらの脂質合成能を [2${ }^{14} \mathrm{C}$ ] acetate の脂質画分への取り込みを指標として検索 を行った。

\section{研究材料と方法}

\section{1. 培養細胞}

癌細胞として, ヒト外陰部由来扁平上皮癌細胞株 $\mathrm{A}$ 431 由来の無蛋白無脂質培地で増殖可能な AJC クロー ン7), 当科で樹立したヒト口腔由来扁平上皮癌細胞株 $\mathrm{UE}^{8,9)}, \mathrm{KA}^{(0)}, \mathrm{NA}^{8,11)}$, 七ト唾液腺由来腺癌細胞株 $\mathrm{HSY}^{12}$ ), $\mathrm{HSG}^{13}$ （徳島大学歯学部口腔外科学第 2 講座 佐藤光信教授より供与), 正常上皮細胞としてヒト口腔 粘膜由来上皮細胞およびヒト唾液腺由来上皮細胞を用い た。

\section{2. 培養液}

RPMI 1640 medium (極東製薬) と Dulbecco's modified Eagle medium(極東製薬)を1：1に配合した培 地 ${ }^{6)}$ (以下, RD と略す) または, modified-MCDB153 medium $^{14)}$ (m'-MCDB 153, 極東製薬) を基礎培地と して, 脱イオン化拈よび逆浸透により純化した水(MilliQ. Milli-pore) を用いて sodium pyruvate $110 \mathrm{mg} / \mathrm{L}$, (片山化学), sodium bicarbonate は RD $2 \mathrm{~g} / \mathrm{L}, \mathrm{m}$ '-
MCDB 153 に $1.2 \mathrm{~g} / \mathrm{L}$ (和光純薬), N-2-hydroxyethylpiperazine-N-2-ethane sulfonic acid $15 \mathrm{mM}$ (HEPES, 同人化学), kanamycin sulfate $90 \mathrm{mg} / \mathrm{L}$, aminobenzylpenicillin $90 \mathrm{mg} / \mathrm{L}$ (以上, 明治製菓) を加え $\mathrm{pH} 7.4$ に調整し, $0.2 \mu \mathrm{m}$ フィルター (Acrocap; Gelman Science Inc.) を用いて濾過隇菌したものを使用した. さら に, crystalline bovine insulin $10 \mu \mathrm{g} / \mathrm{ml}$, human transferrin $5 \mu \mathrm{g} / \mathrm{ml}, 2$-aminoethanol $10 \mu \mathrm{M}$ (以上, Sigma Chemical Co., USA), 2-mercaptoethanol $10 \mu \mathrm{M}$, sodium selenite $10 \mathrm{nM}$ (以上, 片山化学) (以上 5 factors, 以下 $5 \mathrm{~F}$ と略す), fatty acid-free bovine albumin (Pentax Miles Laboratories Inc., USA) $500 \mu \mathrm{g} /$ $\mathrm{m} l$ を加えて使用した。培地中の $\mathrm{Ca}^{2+}$ 濃度は, $\mathrm{RD}$ が $1.12 \mathrm{mM}, \mathrm{m}$-MCDB $0.03 \mathrm{mM}$ であった. growth factor として epidermal growth factor (mouse EGF, Receptor Grade, Collaborative Research, Inc., USA) および, fibroblast growth factor (FGF は，牛脳抽出 液より当科で精製した $\left.{ }^{15)}\right)$ を用いた。

\section{3. 正常細胞の分離培美方法}

1）ヒト口腔粘膜由来上皮細胞

外来小手術時に切除した口腔粘膜より分離培養した. 切除した口腔粘膜から結合組織を可及的に除去後, 0.02 $\%$ ethylenediaminetetraacetic acid (EDTA, 片山化学) を含む Dulbecco's $\mathrm{Ca}^{2+} \mathrm{Mg}^{2+}$-free phosphate buffered saline (CMF-PBS, $\mathrm{NaCl} 8.0 \mathrm{~g}, \mathrm{Na}_{2} \mathrm{HPO}_{4} 1.15 \mathrm{~g}$, $\left.\mathrm{KCl} 0.2 \mathrm{~g}, \mathrm{KH}_{2} \mathrm{PO}_{4} 0.2 \mathrm{~g} / \mathrm{L}, \mathrm{pH} 7.2\right)$ 中で 30 分間処 理し， $0.05 \%$ trypsin (Difco, USA) を含む CMF-PBS 中で $4{ }^{\circ} \mathrm{C}$ 下一昼夜作用させた後, $0.1 \%$ trypsin inhibiter (type II s, Sigma Chemical Co., USA) を含むm'-MCDB 153 培地中で, 実体顕微鏡（オリンパス，K.K. Xr) 下 に自家製ブラシを用いて基底細胞を分離した ${ }^{16)}$. 分離し た基底細胞は， Type I コラーゲン (cell matrix type I -a 新田ゼラチン) コートした $60 \mathrm{~mm}$ 径のプラスチックプ レート（住友ベークライトK.K.）を用いて m’MCDB $5 \mathrm{~F}$ に FGF 1nM を添加した条件で初代培着を行っ た。

2 ）唾液腺由来上皮細胞

恚性腫瘍患者の手術時に摘出した病理組織学的に正常 な顎下腺より分離した．摘出した唾液腺組織を $70 \%$ エタ ノールにて消毒後, CMF-PBS にて洗浄後細切し, コ ラーゲンコートした $60 \mathrm{~mm}$ 径プラスチックプレートを 用いて， RD $5 \mathrm{~F}$ に fatty acid-free albumin を加えた RD 6F に EGF 1nM または FGF 1nMを添加した 条件で初代培養を行った ${ }^{17)}$.

\section{4. 脂質代謝の検索}

コラーゲンコートした $60 \mathrm{~mm}$ 径または $100 \mathrm{~mm}$ 径 プラスチックプレートに無血清培地を用いて 各種細胞 を $\mathrm{RD} 6 \mathrm{~F}$ の条件で植え込み 3 日間培養後, [2- $\left.{ }^{14} \mathrm{C}\right]$ acetate, sodium salt (Amersham. U.K., 1.94 GBq 
$/ \mathrm{mmol}, 7.40 \mathrm{MBq} / \mathrm{m} l)$ を $18.5 \mathrm{KBq} / \mathrm{ml}$ の濃度で添加 し, 一定時間培養後, 冷却した CMF-PBS で 3 回細胞 を洗浄した．次にラバーポリスマンにて細胞を採取し遠 心後, 沈査を試料とした. 同試料のタンパク定量は Bradford ${ }^{18)}$ の方法を用いて行った.

培養は, TE-HER 型インキュベーター（平沢製作所） 内にて, $5 \% \mathrm{CO} 237^{\circ} \mathrm{C}$ の条件下で静置培養を行っ た.

\section{5. 総脂質の抽出方法}

総脂質の抽出は Bligh \& Dyer 法 ${ }^{19)}$ 準じて行っ た. 4. で得た試料に蒸留水 $5 \mathrm{~m} l$ を加え, 超音波破砕器 (UR-200P, トミ一精工) にて粉砕後, メタノール 10 $\mathrm{m} l$, クロロホルム $5 \mathrm{ml}$ を加え15分間振とうした。つい でクロロホルム $5 \mathrm{ml}$ を再度加え, 10分間振とら後蒸留 水 $5 \mathrm{ml}$ を加え, さらに 5 分間振とうした. $1,000 \times \mathrm{g}$ に て 5 分間遠心後, 下層のクロロホルム層を回収した。さ らに残液にクロロホルム $10 \mathrm{ml}$ を加え, 15 分間振とら し $1,000 \times \mathrm{g}$ にて 5 分間遠心後, 下層のクロロホルム層 を再度回収し, 先に得られたクロロホルム画分とともに エバポレーターにて濃縮乾固後, クロロホルム $1 \mathrm{ml}$ を 加え試量とした.

同試料の一部を液体シンチレーター（シンチゾール $\mathrm{EX}-\mathrm{H}$, 和光純薬) と混和後その放射活性を液体シンチ レーションカウンター（ALOKA, LSC-900) にて計测 し全放射活性を得た。

\section{6. 脂質画分の分離法および放射活性の測定法}

5. で抽出した脂質を薄層クロマトグラフィー (TLC) 法を用いて分離分析した. Phospholipids (PL) と free cholesterol (FCh), free fatty acid (FFA), triglyceride (TG), cholesterol ester (ChE) などの neutral lipids (NL) の分離には, 順相系 TLC (silica gel 60, Merk) plate を用い, hexane/diethyl ether/acetic acid (80: $20: 1)^{20)}$ の溶媒系を用いて分離した. sphingomyeline (SM), phosphatidylcholine (PC), phosphatidylserine (PS), phosphatidylinositol (PI), phosphatidylethanolamine (PE)などの PL の分離には high-performanced TLC (silica gel 60, Merk) plate を, 溶媒系として, chloroform/methanol/acetic acid/water (100:60:6: 4) 21)を用いた. 分離後各画分の放射活性をラジオクロマ ナイザー (ALOKA) にて測定した.

\section{7. 培羡正常上皮細胞の脂質代謝の検索}

1) 正常口腔粘膜細胞はコラーゲンコートした $60 \mathrm{~mm}$ 径のプラスチックプレートを用い低 $\mathrm{Ca}^{2+}$ 培地 MCDB $5 F$ に 1nMFGF を添加した条件で継代培着を行った。 検索には $4 \sim 6$ 代の細胞を用いた. subconfluent に達し た細胞を24時間 FGF 非存在下で培湌し, さらに MCDB $5 \mathrm{~F}$ に培地交換後， $\left[2{ }^{14} \mathrm{C}\right]$ acetate を $18.5 \mathrm{KBq} /$ $\mathrm{m} l$ の濃度で添加し 24 時間培養後の脂質代謝を検索し た.
2）唾液腺由来上皮細胞は 1) と同様にコラーゲンコ ートしたプラスチックプレートを用いRD $5 \mathrm{~F}$ に fatty acid-free albumin を加兄た RD $6 \mathrm{~F}$ に $1 \mathrm{nM}$ の EGF あるいは $1 \mathrm{nM}$ の FGF を添加した条件で培養を行っ た。検索には 2 代目の細胞を使用した。 subconfluent に 達した細胞を RD $5 \mathrm{~F}$ のみで 24 時間培養後，さらに RD $5 \mathrm{~F}$ に培地交換し, $\left[2-{ }^{14} \mathrm{C}\right]$ acetate を $18.5 \mathrm{KBq} / \mathrm{ml}$ の 濃度で添加し24時間培養後の脂質代謝を検索した。

\section{8. 培恙癌細胞における脂質代謝の検索}

コラーゲンコートした $100 \mathrm{~mm}$ 径のプラスチックプ レートに, RD $6 \mathrm{~F}$ の条件で各種癌細胞を植え込み, 3 日間培養後 subconfluent に達した細胞を RD $5 \mathrm{~F}$ の条 件で 18時間培養を行い, $\left[2{ }^{14} \mathrm{C}\right]$ acetate を $18.5 \mathrm{KBq} /$ $\mathrm{m} l$ の濃度で添加後 6 時間培養し脂質代謝を検索した.

\section{9. ヒト口腔粘膜由来上皮細胞の分化誘導に伴う脂質 代謝の变化}

正常口腔粘膜上皮細胞をコラーゲンコートした $60 \mathrm{~mm}$ 径のプラスチックプレートを用いて低 $\mathrm{Ca}^{2+}$ 培地 $\mathrm{m}$ MCDB 5F+FGF (1nM) で培養し subconfluentに達し た細胞を FGF 非存在下で 24 時間培養後, RD $5 \mathrm{~F}$ お よびュントロールとして m'-MCDB 5F に培地交換を 行った．交換直後および24時間後に $\left[2-{ }^{14} \mathrm{C}\right]$ acetate を $18.5 \mathrm{KBq} / \mathrm{m} l$ の濃度で添加後それぞれ 24 時間培養し脂 質代謝を検索した。

\section{結果}

\section{1. 正常上皮細胞の脂質代謝の検索}

正常口腔粘膜上皮細胞では，PL 合成能が59.9\%と最 も高く, つついて FCh $17.5 \%$, TG $16.8 \%$, FFA 3.4

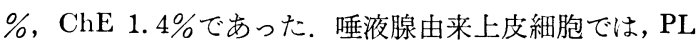
合成能が57.0\%, つついて FCh $27.0 \%$, TG $10.4 \%$, FFA 3.0\%, ChE 1.3\%であった.

\section{2. 培養癌細胞の脂質代謝の検索}

扁平上皮癌細胞 $\mathrm{AJC}, \mathrm{NA}, \mathrm{KA}, \mathrm{UE}$ ではいずれも合 成された脂質の大部分は PL であり，その比率は70\%以 上であった。 また FCh の合成能は13\%から $17 \%$, FFA 合成能は $1.8 \%$ か $5.9 \%$, TG 合成能も $1.2 \%$ か $4.9 \%$ とわずかに垫められた。しかし， ChE の合成能はほと んど認められなかった。一方, 唾液腺由来腺癌細胞 HSG, HSY では PL 合成能が HSG で $36.5 \%$, HSY で38. 9\% と全脂質合成能の内では最も高かったものの他 の細胞と比較して低い比率を示し，TG はHSG で26.1 $\%$, HSY で17.9\%, FCh は HSG で 19.9\%, HSY で16.8\%, FFA は HSG で6.9\%, HSY で 20.4\%, ChE は HSG で $8.9 \%$, HSY で5. $2 \%$ であり扁平上皮 癌細胞と比較して PL に対する NL の合成能の充進が 認められた（表1）.

$\mathrm{PL}$ 合成能に対する NL 合成能の比率 (以下 NL/PL と 
表 1 各種坮養細胞に括ける $\left[2-{ }^{14} \mathrm{C}\right]$ acetate の phospholipids および各 neutral lipid への取り込交 $(\%)$

\begin{tabular}{l|r|r|r|r|r|r|r|r}
\hline & KC & \multicolumn{1}{|c|}{ SE } & NA & UE & KA & AJC & HSG & HSY \\
\hline PL & 59.9 & 57.0 & 71.2 & 78.9 & 78.6 & 74.1 & 36.5 & 38.9 \\
FCh & 17.5 & 27.0 & 13.9 & 13.2 & 17.0 & 16.4 & 19.9 & 16.8 \\
FFA & 3.4 & 3.0 & 6.9 & 6.3 & 2.3 & 1.8 & 6.9 & 20.4 \\
TG & 16.8 & 10.4 & 3.7 & 1.9 & 1.2 & 4.9 & 26.1 & 17.9 \\
ChF & 1.4 & 1.3 & \pm & \pm & \pm & 1.7 & 8.9 & 5.2 \\
\hline
\end{tabular}

PL: phospholipid FCh: free cholesterol FFA: free fatty acid

TG: triglyceride ChF: cholesterol ester

表 2 各種培羞細胞に扣ける $\left[2-{ }^{14} \mathrm{C}\right]$ acetate の各 phospholipid への取り込み 率 $(\%)$

\begin{tabular}{l|r|r|r|r|r|r|r}
\hline & \multicolumn{1}{|c|}{ KC } & \multicolumn{1}{c|}{ NA } & UE & KA & AJC & HSG & HSY \\
\hline SM & 3.1 & 4.8 & 7.2 & 7.6 & 10.5 & 7.4 & 8.6 \\
PC & 50.9 & 54.0 & 60.7 & 56.3 & 69.8 & 63.1 & 45.1 \\
PS +PI & 14.4 & 14.8 & 13.3 & 11.7 & 10.3 & 14.0 & 17.2 \\
PE & 31.6 & 26.4 & 19.3 & 26.0 & 9.5 & 15.6 & 30.0 \\
\hline
\end{tabular}

SM: sphingomyelin PC: phosphatidylcholine PS: phosphatidylserine PI: phosphatidylinositol PE: phosphatidylethanolamine

略す）は，正常口腔粘膜細胞では0.65, 正常唾液腺上皮 細胞では0.73であった。一方, 扁平上皮癌細胞では UE が0.4, NA が0.36, KA が0.26, AJC が 0.33 と低值 を示し, 唾液腺癌細胞 HSG では1.69, HSY では1.56 と高值を示した（図1）。このように NL/PL は, 扁平 上皮癌細胞では正常上皮細胞より低值を, 腺癌細胞では 正常上皮細胞より高值を示すことがあきらかとなった.

\section{3. 各種培養細胞における各 PL 合成能の検索}

今回検索したすべての培峑細胞において，合成された PL のらち PC 合成能が最も高くつついて PE であっ た (表 2). 正常細胞と癌細胞間で, あるいは, 扁平上 皮癌細胞と腺癌細胞間であきらかな差を認めなかった。

\section{4. ヒトロ腔粘膜由来上皮細胞の分化誘導に伴う脂質 代謝の变化}

分化を抑制した条件では，PL が59.9\%と最も高く， つづいて FCh 17.5\%, TG 16.8\%, FFA が3.4\%認め られた，通常濃度の $\mathrm{Ca}^{2+}$ を含む $\mathrm{RD} 5 \mathrm{~F}$ 培地で分化 を誘導すると, 分化誘導後24時間では, FCh 合成能が 40.9\%と著明に増大し， PL および TG は48.1\%およ び6.8\%とともに低下した（表 3). 培地交換後48時間後 でも同様に，FCh 合成能の増大と PL および TG の 低下を認めた．分化抑制条件と分化誘導条件での NL/ PL を比較すると，分化抑制条件では 24 時間後 $0.65,48$ 時間後 0.62 , 分化誘導条件では 24 時間後 $1.05,48$ 時間後 1.01であり，分化に伴い NL/PL 值が上昇することが
表 3 培養正常口腔粘膜上皮細胞の分化誘導に伴 5 [2-14C] acetate の phospholipids および各 neutral lipid ヘの取り込み率 $(\%)$

\begin{tabular}{l|c|c|c|c}
\hline \multirow{2}{*}{} & \multicolumn{2}{|c|}{$24 \mathrm{~h}$} & \multicolumn{2}{c}{$48 \mathrm{~h}$} \\
\cline { 2 - 5 } & MCDB & RD & MCDB & RD \\
\hline PL & 59.9 & 48.1 & 60.6 & 48.9 \\
FCh & 17.5 & 40.9 & 22.6 & 34.4 \\
FFA & 3.4 & 2.9 & 2.6 & 5.3 \\
TG & 16.8 & 6.8 & 12.5 & 9.8 \\
ChE & 1.4 & \pm & 0.7 & \pm \\
\hline
\end{tabular}

MCDB: $\mathrm{Ca}^{2+}, 0.03 \mathrm{mM}$ RD: $\mathrm{Ca}^{2+}, 1.12 \mathrm{mM}$

あきらかとなった（図 2).

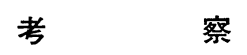

われわれは癌細胞の組織型の違いによりその細胞内へ の種々の抗癌剤の取り込みに差があることを，また，そ の薬剤感受性に差があること年2 をあきらかにしてきた. つまり, 親水性の抗癌剤であるシスプラチンや 5-FU は, 扁平上皮癌細胞に比較し腺癌細胞に高濃度に取り込 まれ, 抗腫瘍効果も腺癌細胞に対して高いこと泉を, ま 


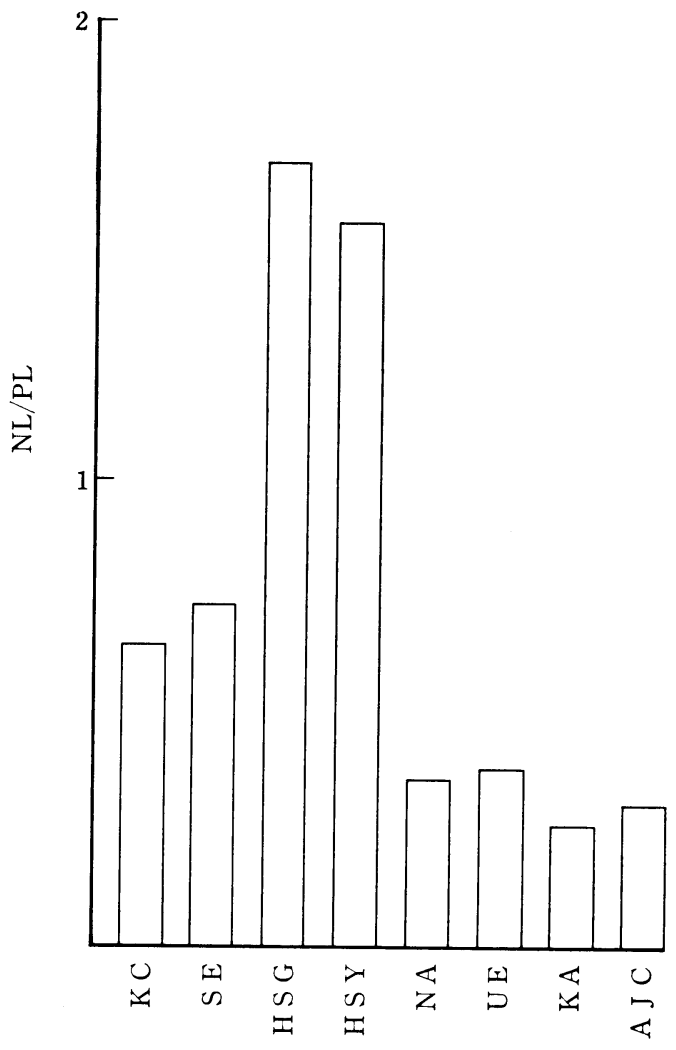

図 1 各種培㽰細胞に扣ける NL/PL

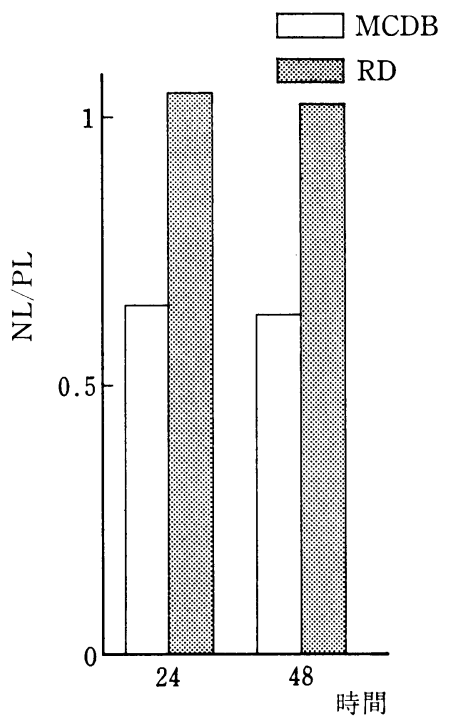

図 2 培養正常口腔粘膜上皮細胞の分化誘導に伴 5 NL/PL の変化
た，柾水性の光感受性色素であるへマトポルフィリン誘 導体やフェオフォバイド - $\mathrm{a}$ は, 腺癌細胞に比較し扁 平上皮癌細胞に高い濃度で取り込まれ，抗腫瘍効果も扁 平上皮癌細胞に対して高いこと1)を，さらにこれら薬 剤の細胞内への取り込みは, 細胞膜の受動輸送によるこ と ${ }^{1,2)}$ をあらかにしてきた。これら癌細胞における薬 剂の取り込みの差は細胞膜の脂質構造の違いに基づく細 胞膜の疎水性の差を反映していると考えられる. 一方, 培養細胞に打ける脂質合成能や脂質組成の検索 ${ }^{21 ~ 23)}$ は 従来, 血清存在下で行われている. 血清中にはリポ蛋白 を中心とした脂質や未知の因子が存在し，また血清の口 ット間でこれら脂質の組成や量が異なるため, 血清存在 下では細胞が本来持つ脂質合成能や脂質組成を正しく検 索することはできない。そこで本研究では，脂質をまっ たく含まない当科で開発した無血清培地 ${ }^{6)}$ を用いて各種 培養細胞の脂質合成能の検索を行った。

口腔粘膜由来正常上皮細胞扣よび唾液腺由来上皮細胞 では PL 合成能が最も高く，つづいて，FCh，TG を認 め, 口腔粘膜由来上皮細胞と唾液腺由来上皮細胞は注 同様の脂質合成能を示した，NL/PL は口腔粘膜由来上 皮細胞が 0.65 , 唾液腺由来上皮細胞が 0.73 であった。

Ponecら ${ }^{21)}$ は血清添加培地を用いて表皮由来keratinocyte の脂質代謝を検索し，PL 合成能が最も高く，つつい て TG, ChE が認められ，FCh はごくわずかしか認め られなかったと報告している。われわれの無血清培地で の結果では17.5\%の FCh 合成を認めた，彼らとわれわ れの結果ではこのように FCh 合成能に大きな差が存在 するが，これは由来組織の差はあるものの血清中のコレ ステロールにより keratinocyte のコレステロール 合成 の律速酵素である HMGCoA Reductase ${ }^{24)}$ の活性が抑 制された結果であると考えられ，彼らは細胞本来ではな く血清中の脂質に修飾された脂質合成能をみていると考 えられる。

扁平上皮癌細胞 $\mathrm{UE}, \mathrm{NA}, \mathrm{KA}$ および $\mathrm{AJC}$ では, 合成された脂質の $70 \%$ 以上は $\mathrm{PL} て ゙ ， \mathrm{FCh}, \mathrm{FFA}$ ， TG などの NL もわずかに認め, NL/PL は $0.26 〜 0.40$ と 低い值を示した。一方, 腺癌細胞 HSG, HSY では, PL 合成能は扁平上皮癌細胞と比較して低下し，FCh，TG， FFA，ChE の増大を認めた. NL/PL は HSG が1. 69, HSY が1.56と中性脂質合成能の割合が大きくなり，扁 平上皮癌細胞と腺癌細胞間では脂質代謝に大きな差があ ることがあさらかとなった. Ponec ${ }^{21)} ら は ，$ 血清添加培 地を用いて検索を行い, 分化度の低い表皮由来扁平上皮 癌細胞ほど PL 合成能が高く, また, いずれの扁平上 皮癌細胞も NL/PL が0.5 以上であったと報告してい る. 本研究に用いた扁平上皮癌細胞間では分化度の差に よる脂質合成能の差は認められなかった。

動物細胞の基本的な細胞膜を構成する PL は, 主に PC, PS, PI, PE, SM の 5 種類と考えられている ${ }^{25)}$. 
今回検索した培着細胞では合成された PL の大部分は PCで,つづいて PE であった. 正常細胞と癌細胞間で, あるいは, 癌細胞の組織型によってその PL 合成能に 特徵的な差は認められなかった。 Ponec ら $5^{21)}$ も合成さ れた PL の多くはPC，つづいて PE であり，また， 表皮由来 keratinocyte と表皮由来扁平上皮癌細胞で差 を認めていない，また，正常細胞と癌細胞の脂質合成能 を比較すると, 扁平上皮組織では, 分化度の高い口腔粘 膜由来上皮細胞が扁平上皮癌細胞よりも中性脂質合成能 が高かった。このように正常細胞と扁平上皮癌 細胞で NL/PL に大きな差を認めた。さらに， 口腔粘膜由来上 皮細胞の分化誘導に伴い著明な Fch の増大と PL, TG の減少を認め，NL/PL は分化とともに24時間では 0.65 から1.05，48時間後では0.62から1.01とあきらかに增大 した.

従来, 培養表皮 keratinocyte の分化の指標としては,

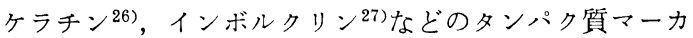
一が用いられてきた。

一方, Hennings ら ${ }^{28)}$ により in vitro においてマウス 表皮 keratinocyte の增殖と分化が 培地中の $\mathrm{Ca}^{2+}$ 濃度 により制御されていることが報告されて以来，培地中の $\mathrm{Ca}^{2+}$ 濃度調節による表皮 keratinocyte の分化誘導に伴 丂脂質代謝や脂質組成の研究も行われている. Okamoto ら ${ }^{29}$ は分化に伴い cholesterol 合成の中間代謝物である lathosterol の合成が亢進することをあきらかにし，ま た Ponec ${ }^{21)} ら は$ 分化に伴い NL/PL 值が上昇すること をあきらかにしている。しかし，それらはいずれも $10 \%$ 血清添加培地を用いた検索結果であり，血清中の脂質に よる影響を受けていることを否定できない。われわれの 結果から NL/PL とりわけ $\mathrm{FCh} / \mathrm{PL}$ 值は正常上皮細胞 の分化の指標となり得ることが，また癌化に伴い分化度 の低下とともに同值の低下をきたすことがあきらかとな った。

今回われわれは，全細胞の脂質合成能について報告し たが，遠心分画法により細胞内の各構成成分に拊ける脂 質合成を検索した結果，細胞膜への新たに合成された脂 質の取り込みと全細胞の脂質合成能との間に差を認めな かった（未発表データ）。したがって今回検索した脂質 合成能が細胞膜の脂質組成を反映しており, 腺癌細胞と 比較して扁平上皮癌細胞の膜の蹯水性はより高いと考兄 られ，親水性の抗癌剂が腺癌細胞に取り込まれやすく， 疎水性の抗癌剤が扁平上皮癌に取り込まれやすいといら 結果を説明することができる。これらのことから癌細胞 膜の脂質組成に応じたりポゾームを作成し，リポゾーム 一抗癌剂複合体あるいは癌細胞膜の疎水性に応じた抗癌 剤を選択することにより, 薬剤の癌細胞内濃度を選択的 に上昇させることが可能となり，高い治療効果が期待て きると考えられる。

\section{結語}

著者らは無血清培地を用いてロ腔粘膜由来ならびに唾 液腺由来正常上皮細胞および口腔癌細胞の培養を行い, $\left[2-{ }^{14} \mathrm{C}\right]$ acetate の脂質画分への取り込みを指標として 各細胞の脂質合成能を検索し以下の結果を得た。

1. 口腔粘膜由来正常細胞では PL 合成能が最も高く つづいて FCh，TG，FFA，ChE が認められた。唾液腺 由来上皮細胞においても口腔粘膜由来正常細胞とほぼ同 様な脂質合成能を認めた。

2. 扁平上皮癌細胞ではいずれも合成された脂質の大 部分は PL で，FCh，FFA，TG もわずかに認められ た。しかし，ChE は認められなかった。また，NL/PL は低值を示した。

3. 唾液腺癌細胞では PL 合成能は扁平上皮癌細胞よ りも低下し，FCh，FFA，TG， ChE の増大を認め, NL/ PL は高值を示した。

4. すべての培養細胞において合成された PL のうち PC 合成能が最も高く, つづいて PE であった。正常 細胞と癌細胞間で，また，扁平上皮癌細胞と腺癌細胞間 で合成された PL の組成にあきらかな差を認めなかっ た.

5. ヒト口腔粘膜由来上皮細胞の分化誘導に伴い FCh 合成能の增大と PL, TG の低下を認めた。分化に伴 い NL/PL，とりわけ FCh/PL は上昇した。

以上の結果から正常上皮細胞の分化の指標としてNL/ PL が有用であること, 癌化に伴い同值が低下すること があきらかとなった．また扁平上皮癌細胞は腺癌細胞に 比較して膜の疎水性が高いことが示唆された。

\section{引用 文 献}

1）虎谷茂昭, 岡本哲治, 他：フェオフォバイドー $\mathrm{a}$ を用いた光力学療法の基礎的研究. 第50回日 本癌学会総会記事 4281991.

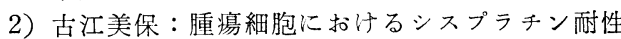
の温熱による克服。日口外誌 $37: 1217-1233$ 1991.

3) Spector, A., Mathur, S., et al.: Lipid nutrition and metabolism of cultured mammalian cells. Prog Lipid Res 19: 155-186 1981.

4) Barnes, D. and Sato, G.: Serum-free cell culture: a unifying approach. Cell 22: 649-655 1980.

5) Barnes, D. and Sato, G.: Methods for growth of culture cells in serum-free medium. Anal Biochem 102: 255-270 1980.

6) Myoken, Y., Okamoto, T.,et al.: An alternative method for the isolation of NS-1 hybridomas using cholesterol auxotrophy of NS-1 mouse 
myeroma cells In vitro Cell Dev Biol 25: 477-480 1989.

7) Myoken, Y., Kayada, Y., et al.: Vascular endothelial cell growth factor (VEGF) produced by A-431 human epidermoid carcinoma cells and identification of VEGF membrane binding sites. Proc Natl Acad Sci 88: 581958231991.

8) Miyauchi, S., Moroyama., et al.: Malignant tumor cell lines produce interleukin-l-like factor. In vitro Cell Dev Biol 24 :753-758 1988.

9) 宮内 忍, 諸山隆正, 他: 煩粘膜扁平上皮癌由 来細胞株によるインターロイキンー1 様物質の 産生. 日口外誌 34: 7-14 1988.

10) Dianging, Wu., Mikio, Kan, et al.: Characterization and molecular cloning of a putative binding protein for heparin-binding growth factors J Biol Chem 266 1991. (in press)

11）宮内 忍, 諸山隆正, 他: 人口腔癌由来細胞株 (Ueda-1) の樹立. 日口外誌 31：1347-1351 1958.

12) Yanagawa, T., Hayashi, Y., et al.: Generation of cells with phenotypes of both intercalated duct-type and myoepithelial cells in human parotid gland adenocarcinoma clonal cells grown in athymic nude mice. Virchows Arch [B] 51: 187-195 1986.

13) Shirasuna, K., Sato, M., et al.: A neoplastic epithelial duct cell line established from an irradiated human salivary gland. Cancer 48: 745-752 1981.

14) Tsao, M.C., Walthall, B.J., et al.: Clonal growth of normal human epidermal keratinocytes in a defined medium. J Cell Physiol 110: 219-229 1982.

15) Crabb, J.W., Armes, L.G., et al.: Characterization of multiple forms of prostatropin from bovine brain. Biochem Biophys Res Commun 136: 1155-1161 1986.

16) Yuspa, S.H. and Harris, C.C.: Altered differentiation of mouse epidermal cells treated with retinyl acetate in vitro. Exp Cell Res 86: 95-105 1974.

17）尾崎煇彦, 岡本哲治, 他：口腔由来正常上皮細 胞扣よび口腔癌細胞の無血清培養下での増殖に 及ぼす EGF, FGF の影響ならびにこれら細 胞に打ける受容体解析。 日口外誌 37 : 145414651991.
18) Bradford, M.M.: A rapid and sensitive method for the quantitazation of microgram quantities of protein utilizing the principle of protein-dye binding. Anal Biochem 72: 248-254 1976.

19) Bligh, E.G. and Dyer, W.J.: A rapid method of total lipid extraction and purification. Can J Biochem Physiol 37: 911-917 1959.

20) Anders, P. and Armand, G.: Solvents for thin layer chromatography of blood serum lipids. Nature 212: 402-403 1966.

21) Ponec, M., Kempenaar, J., et al.: Regulation of lipid synthesis in relation to keratinocyte differentiation capacity. Biochim Biophys Acta 921: 512-521 1987.

22) Williams, M.L., Rutherford, S.L., et al.: Density-dependent variations in the lipid content and metabolism of cultured human keratinocytes. J Invest Dermatol 91: 86-91 1988.

23) Ponec, M., Weerheim, A., et al.: Differentiation of cultured human keratinocytes: Effect of culture conditions on lipid composition of normal vs malignant cells. In Vitro Cell Dev Biol 25: 689-696 1989.

24) Joseph, L.G. and Michael, S.B.: The lowdensity lipoprotein pathway and its relation to atherosclerosis. Ann Rev Biochem 46: 897-930 1977.

25) Alberts, B., Brey, D., et al.: Molecular biology of the cell. 2nd Ed, Garland Publishing Inc. New York \&London, 1989, p 280.

26) Fuchs, E. and Green, H.: Regulation of terminal differentiation of cultured human keratinocytes by vitamin A. Cell 25: 617-625 1981.

27) Watt, F.M. and Green, H.: Stratification and terminal differentiation of cultured epidermal cells. Nature 295: 434-436 1982.

28) Hennings, H., Michael, P., et al.: Calcium regulation of growth and differentiation of mouse epidermal cells in culture. Cell Cell 19: 245-254 1980.

29) Okamoto, T., Moroyama, T., et al.: Differentiation of cultured epidermal keratinocytes related to sterol metabolism and its retardation by chemical carcinogens. Biochim Biophys acta 805: 143-151 1984. 